\title{
The linguistic world of field colonialism
}

\author{
WILLIAM J. SAMARIN \\ Department of Linguistics \\ University of Toronto
}

\section{ABSTRACT}

In the last decade of the nineteenth century, when pidginized Sango became the vehicular language of the Ubangi River basin, colonization by the French and Belgians was accomplished with little direct linguistic contact between the whites and the indigenous populations but with great reliance on the real or assumed linguistic skills of their foreign African personnel. The whites' use of African languages was limited with respect to the referential function but powerful with respect to the expressive or affective. (Colonization, Africa, Sango, pidginization, ethnography of communication)

Although the study of pidgins and creoles has matured to a remarkable degree in the last twenty years, as manifested both in the number of works that have been published and also in the variety of perspectives that have been brought to the subject, less progress has been made proportionately in understanding how pidgins have emerged in different situations. There has been an understandable emphasis on the theoretical linguistic aspects (such as Bickerton I 984, criticized in Samarin I984b), but in spite of repeated calls for more sociolinguistic and historical research, few have yet given themselves to this task (for which Baker \& Corne [1982] and Mühlhäusler [1983] would be exceptions).

Since it has been generally believed that Europeans played an important role in the process that led to pidginized languages, this topic has had special attention in my research on the history of Pidgin Sango, by decree the "national language" of the Central African Republic since independence. The question has been investigated from two perspectives: the demographic and the "intellectual." This paper deals with the latter. My thesis is that the manner in which Europeans communicated with central Africans - a process that is best seen as a dialectic one - was constrained by culturally conditioned "knowledge." Since the history of Sango is linked sociolinguistically to that of Lingala and Kituba, what is said here applies, with minor adjustments, to the histories of all three pidginized languages. 
When they began to penetrate the heart of Africa in the nineteenth century, whites must have felt as if they were going to the end of their own world. This was where there were vast blank areas on their maps, and when they entered, whether by water or by land, they encountered a world entirely different from their own.

In leaving Europe whites did not, however, leave all behind. They brought with them food, wine and spirits, medicines, instruments, tools, and arms. Above all, they brought "knowledge" - what they "knew" about the world: ideas of duty, patriotism, work, and morality; they knew what it meant to be a human being, and they knew what it meant for others to be "savage."

The history of the conquest and colonization of Africa cannot be written without taking into account this intellectual world into which the white was born, and in which he lived and had his being. From this perspective, colonization is an "extension" of European life - better yet, it is, on the one hand, "experimental civilization," where European ideas could be tested with new data, and, on the other hand, "applied civilization," where European ideology could be used for "the good of mankind."

This study deals only with the linguistic aspects of colonialism, and it deals with what happened when Europeans came into contact with the forest- and grassland-dwelling people of central Africa.

The linguistic notions of Europeans had been formed by normative grammar with which they had been indoctrinated. Some may have studied Latin, and only a very few Greek. Their ideas could not yet have been informed by the developing science of linguistics. For example, when Joseph Briand went to Bangui in I 898 as a medical doctor at the age of 22 , he seemed to have been linguistically innocent. Whatever skill he acquired in communicating with the local people, he attributed it - and obviously in jest - to the Breton he had learned from the old household servant (Dias-Briand 1982)!

Ignorance and knowledge are, of course, variable over space and time. Yet an intellectual history of Africa would have to account for very great differences between the linguistic "worlds" of the English, French, and Germans. These, naturally, would be related to the sociopolitical structures in the respective nations. This history, unfortunately, is not ready-to-hand, but it should be noted that it was not until 1962 that African linguistics was taught in France at the university level. (For a history of African linguistics in France, see Bouquiaux [1982].)

Linguistic knowledge and linguistic curiosity did not depend accidentally on the personal histories of whites who went to Africa but on the social structures which had formed them. It is not surprising therefore that missionaries would have had more interest in the native languages and that Protestants would have 
been even more committed to learning them than Catholics. (On Protestant missionary linguistics, see Wonderly \& Nida [1963].) Yet the differences are so striking that they must be noted.

The English who served with the Baptist Missionary Society first in the Cameroun and then in the Congo River basin were from what the French would call the working class; if not that, then certainly the lower middle class as we would call it today - certainly not the "bourgeoisie." One would not have expected from this society persons of such intellectual assiduity and competence as W. Homan Bentley, Walter H. Stapleton, and John Whitehead, whose works on Kongo, Bangala, and Kibangi can be appreciated even today. Note that in I884, Bentley had published in the Missionary Herald (October I, p. 374) an appeal for books on Africa, especially of linguistic nature. There would have been available to him in English by this time Cust's $A$ sketch of the modern languages of Africa ( 1883 ) and Lepsius's Standard alphabet for reducing unwritten languages (I 855). Including those two works, Meinhof and van Warmelo (1932) cite eight works in English and three in German published between I 854-I883 relevant to their survey of Bantu languages. For the period I 854-1899, the inventory is this: twelve in English, eight in German, two in French, and one in Portuguese. (For a survey of the history of African linguistics, see Alexandre [1967], Cole [1971].) However it was that Bentley had already acquired his openness to African linguistic structures, note should be taken of his appreciation of the Kongo (his Kixhi Congo) language: "The language spoken at San Salvador is no barbarous jargon; rich, flexible, and precise, it is in no way to be despised. Its grammar can be reduced to definite rules ..." (Missionary Herald, I884:2 I0).

Catholic missionaries eventually produced work of similar excellence, for example, the Scheutist Égide de Boeck. But here, too, differences must be observed. Whereas the Belgian Scheutist and Capuchin missionaries and the German White Fathers made valuable studies, the French Holy Spirit missionaries did nothing equal; and Tisserand's work on Banda is hardly an exception.

Both the reading of archives from the last quarter of the nineteenth century and of published accounts of personal experiences and also an understanding of the societies from which these whites (e.g., French, English, Belgian, Italian, and Scandinavian) came lead one to believe that for the most part they left their homeland with practically no conception of what African languages were like except that, like the people who spoke them, they were simple and could be easily learned - that is, if one wanted or had to learn them. That qualification is terribly important. It is not to be taken for granted that whites would want, for any reason, to learn more than was immediately necessary. How they exercised their will in this matter was itself part of their "cultural baggage." This is made clear in the exposition that follows. The fact that whites presented themselves as better "linguists" than they were is clearly part of African history, for which see Samarin (1982b). For example, Van Kerkhoven pointed out that when he arrived 
in the Congo in April I883, "il ne savait nullement comment se faisaient les palabres avec les indigènes, ni de quelle façon il fallait se comporter avec eux" (Delcommune I922(I): I65, I66).

Inevitably (that is, as a consequence of the field situation), whites picked up odd bits of information, first on the month-long ship voyage to the west coast of Africa, and then from other whites (for wordlists seem to have been shared) and from their black employees. (It is my belief that whites had very little direct contact with indigenous peoples. The thesis is argued in Samarin [1982a] and [1982b].)

This way of "learning" African languages - casual and anecdotal - must be related to the way whites learned much about the people with whom they were going to come in contact. A great deal of field ethnography was acquired orally, through conversations at meals or through the long hours of steamboat travel (one month from Brazzaville to Bangui, for example), when stories were exchanged as much for amusement as for information.

We can learn a great deal about the linguistics (or folk linguistics) of these nineteenth-century whites by what they said about their language learning. For example, Jeannest said, "Il est extrêmement utile de connaître un peu le language des indigènes" ( I883:6I-62, emphasis added). And although Coquilhat went to Africa knowing apparently nothing about Congolese languages, he claimed to have acquired competence in Swahili, Kibangi, Kilolo, Kiteke, and "Bangala"' in a very short time (1888:99, I47, I96). But what he thought of these languages and what he believed about knowing African languages is revealed by the fact that he did not use the verb 'speak' but 'jabber' (baragouiner) when describing his linguistic activities. The study of colonial folk linguistics will therefore be an enlightening perspective on the nature of the contact between Europeans and peoples relatively untouched by Western civilization. It will also contribute to linguistic scholarship as outlined by Hoenigswald (1966).

Having observed in a general way the linguistic world of colonization in central Africa, we shall now turn to examine its consequences in the Ubangi River basin. (For political histories, see de Mazières [1982], Kalck [1974], and Prioul [I98I]. Samarin [1984c] is concerned with the recruitment of indigenous labor and its significance in the emergence of a Ubangian lingua franca.)

\section{THE ETHNOLINGUISTIC CHALLENGE}

Virtually nothing in the previous experience of most of the newcomers into the Ubangi basin could have prepared them for linguistic intercourse with the local populations. Although advances had been made in the study of western equatorial languages since Stanley pioneered his way into the interior, all of this had to do with so-called Bantu languages, which are found along the course of the Congo River all the way from Stanley Falls/Kisangani to its mouth. Non-Bantu languages were, of course, early identified inland from the right bank (that is, 
north) of the river from Bangala, the major center of the Congo Independent State from as early as I884 (Hanssens I 892:39) to Stanley Falls. In fact, at the eastern end of the river, non-Bantu languages were found on its very banks. A few of these non-Bantu languages also were the objects of linguistic curiosity. Any one of them would have been typologically instructive to the serious and intelligent white or black who found himself on the Ubangi River, but Mongwandi would have had the most direct utility for exploring the Ubangi; it is part of the Ngbandi-Yakoma-Sango (etc.) cluster of dialects.

On the Ubangi River, these non-Bantu languages (until quite recently called "Sudanic") extended a half or two-thirds of the way southward in its lower reaches. The first speakers of these languages would have been the "Bondjo." This was an ethnic name attributed to most or all of the people upriver of the Baloi, Afuru, and Bobangi (Bantu-speaking peoples), who, regardless of their similarities, spoke forms of at least three languages: Gbanziri (including Monzombo, Buraka, and Ngbaka-Ma'bo), Ngbaka-Gbaya (including Mandjia), and Banda (Samarin 1984a). Beyond the Gbanziri, and as far as the bifurcation of the Ubangi into the Wele and the Mbomu, is found once again the cluster of Sango-Ngbandi-Yakoma-Dendi dialects.

All of these languages are sufficiently homogeneous typologically that the learning of one would have contributed much to the learning of another. These languages are in fact all related genetically, being members of the Ubangian phylum (Samarin 197I; Thomas I963), introduced under the name "Eastern" by Greenberg (1963). And what is more important for language learning is that within each of the dialect clusters there is a high level of uniformity - with exceptions, as one would expect.

This Ubangian linguistic similarity (of the nature possibly of Scandinavian and continental Germanic languages before their standardization) would have led, one supposes, to a certain amount of multilingualism. But that depends, of course, on interethnic contact. That there was a considerable amount of this the nineteenth-century records make quite clear - between riverine populations on the one hand and between these and inland populations on the other. (This "water" vs. "bush" distinction was conscious to the degree that it was lexicalized in several of the languages; in other words, these populations had a "them" and "us" distinction on this basis.) In addition to more or less peaceable relations that characterized, for example, trade, there would have been bellicose ones that led to the capturing and enslaving of individuals. These captives would have become bilingual and would have been used in subsequent interethnic contacts. These very individuals, then, would also have served the French (assuming, of course, that it was to the advantage of the masters to lend them). This topic, while critical to the present study, cannot be fully explored here. Ubangian ethnohistory has not advanced far enough for us to be adequately informed. Nonetheless, I can cite what evidence has been collected about possible multilingualism. 


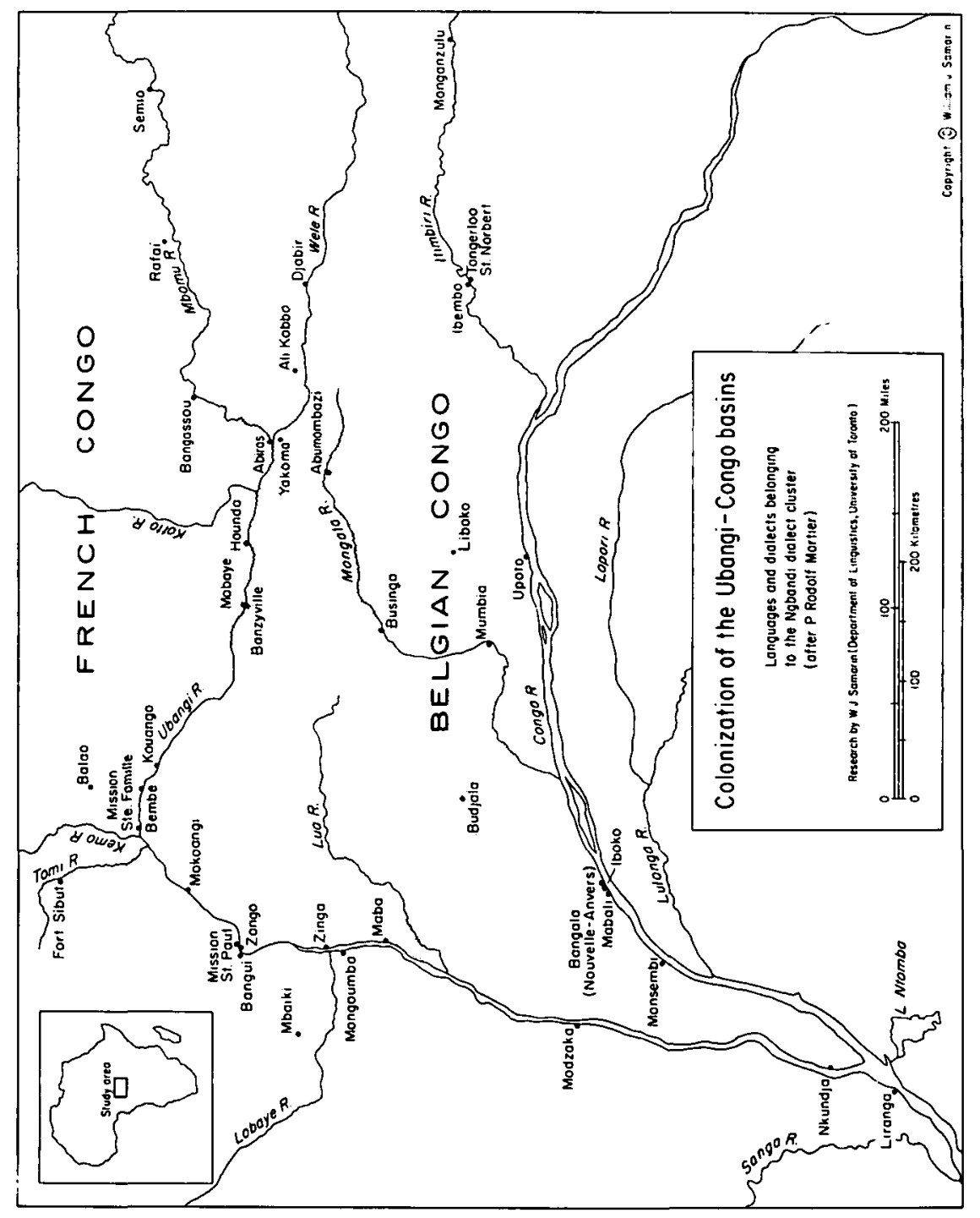


In 1889 , just six months after the post had been established at Bangui, a chief from a nearby village acted as guide to an area that is not identified in the records. However, he would not travel further after the third day because, he claimed, there would not be any food and because the populations did not speak his own language. (We can assume that food could be obtained as long as one could rely on intraethnic relations, such as kinship obligations. These so-called chiefs had no real power of the kind found in other African societies.) The white insisted on continuing anyway but found that, indeed, they could not make themselves understood. (The source is Archives Nationales [AN] 4(3)DI, Bangui, 20 November 1889 , the signature of which, difficult to read, seems to be Albert. This must have been Dolisie, a former student at the École polytechnique and already decorated at twenty-nine years of age [Musy I 890:455], who established the French at Bangui.) Although the chief's village is not named (but for a list of these, see below), I speculate that he was Ngbaka. If the other group did not speak Ngbaka, they were speakers of either a Banda dialect or GbayaNgbaka.

To the east, between the Tomi and the Kemo Rivers, are found Togbos who speak a Banda dialect, located by Maistre, who went through their territory in July I 892, about $50 \mathrm{~km}$ from Ouada on the Ubangi (Maistre 1893 : map). Julien's map (1902, based on a much earlier manuscript) places them closer. (From Bembe, just $75 \mathrm{~km}$ further east, Crampel had gone north in I 890 and Dybowski in I891.) The Togbos' language seems to be known to Manguendjo, one of their guides, a Gbanziri from the settlement at Ouada. Brunache, who was on this expedition, says that on meeting Crouma, one of the Togbo chiefs, Manguendjo explains the visit to him, adding, "Cet aimable Banziri commence à être pénétré de ses fonctions d'introducteur des ambassadeurs et s'en acquitte à merveille" $(1894: 84,70)$. But on the very next page there is something that casts doubt on his being a Gbanziri. Brunache says, "un 'Banziri' prend le chef à part et lui parle un moment à l'oreille" (1894:85). The fact that one of their companions spoke privately and intimately to the chief suggests that they shared a language, but the person is identified as a "Gbanziri," suggesting an ambiguous identification.' This indeed is a puzzle, because Brunache had said earlier (page 3I) that the Gbanziri knew the Togbos only by hearsay! The location of Crouma's village might be north of Azamgounda (if Maistre's Azangouanda is the same), because Brunache says (if I interpret correctly) that this chief is one of the first encountered north of Bembe (I 894:I49). Krouma is an ethnic name located on Dybowski's map of $189 \mathrm{I}-\mathrm{I} 892$ just west of Yabanda. This was close enough to Bembe that their guide, Ali, was on excellent terms with the chief, and all the villagers seemed to know him (Brunache I 894:I49). The identification of Ali has some importance in this study. Although he may have been a Senegalese (since his name is a Muslim one) stationed at Ouada, he might also have been the Ndri mentioned below.

Brunache confuses the matter even more on later pages. First he informs us of 
the mutual intelligibility of the Banda dialects from the Kemo River to the right bank of the Vassako river (almost $400 \mathrm{~km}$ from the Ubangi River by my estimate) on the grounds that "our little Togbo, the little Ndris," and the two women (additions to the contingent of guides) made themselves understood easily ( $1894: 205)$. He calls this language Ndri and says that it is spoken from, on the one hand, where the Ngapu (N'gapoux) live (about $225 \mathrm{~km}$ north of Bembe, according to Dybowski's map of $189 \mathrm{I}-\mathrm{I} 892$ and Crampel's of $\mathrm{I} 890$ ) to near Bangui, and, on the other hand, from the Ubangi River to about $8^{\circ}$ north. Then he says that the riverine peoples - the "Sangos," Gbanziris, Bondjos, and Buzerus - do not use Ndri habitually, but practically all of them speak it ( $1894: 206$ ). Moreover, it is this language whose words have contributed to the making of "a sort of patois" by "our men" (presumably the Senegalese soldiers), which enables them to make themselves understood easily as far as the Vassako. This, then, must have been a Banda-based jargon that the French blacks were using (Samarin, n.d.).

Another case in the year 1892 also involved a Togbo, once again a young person, if not a child, named Mahdi Diop. It is recorded that he was used in negotiating with the Mandjias (Maistre I895:83, IOI, I02), whose language is related to Gbaya and Ngbaka-Gbaya, entirely different from Banda. Since his name is a Muslim one from west Africa, I would suppose that the Senegalese soldiers gave it to him. He might have been in their service at Ouada. If that were so, he could have been a Mandjia captive of the Togbos. But since Maistre elsewhere writes about discovering among the Togbos or Ndris (I speculate) someone who had escaped captivity among the Ouada Muslims shortly before they come upon the Mandjias (say, June-July 1892), this may be the same person (Maistre I 893:275).

There are two other accounts of this experience of Maistre's. First, Gentil, in a contemporary government document, wrote that Maistre had trouble with the Mandjias, specifically at Ungourras, due to a misunderstanding that could have been avoided if he had had an interpreter (Gentil, AN 2DI I). On the other hand, Legendre romanticises the event for the glory of France by misrepresenting the speech event: "Maistre se rend presque seul près de leur chef et, après un palabre émouvant, blanc et noir se donnent la main: la paix est faite . . ." (Legendre 1903: I 80).

\section{THE USE OF INTERPRETERS}

If colonization was a matter of politics and economics in Europe, on the Ubangi River in the early days it meant making contact with the natives, finding food for the black personnel, setting up the nightly camps, and negotiating land rights. After the initial contacts, the material development of the "posts" (stations or forts) with the increasing need for canoes and canoers presented greater communicational challenges: Negotiations for resources and labor must certainly have 
put a strain on linguistic competence. Another and amusing perspective, however, is given by P. Rémy, who says, in all seriousness, "Pour la fondation d'une Mission, trois choses sont absolument nécessaires: le bois, l'eau et les poulles . . ." (Congrégation du Saint-Esprit et du Saint-Coeur de Marie, Paris [CSEP] III. I70-A.5).

Here and elsewhere, the present history of Sango is unfortunately not adequately informed by accounts of earlier expeditions up the Ubangi River except for the following account. When Captain Hanssens, in the service of the Belgians, went up the Ubangi for the first time in 1884 , he was accompanied on the steamer En Avant by "son interprète," as Van Gèle (1930) puts it. Through this intermediary, blood was exchanged and a treaty was made with "le Grand Chef Makoko," otherwise known as Nkoko (Van Gèle 1930:37). Since Harms (I978) has established that there were Bobangi villages on the Ubangi near its mouth, it is reasonable to suppose that the interpreter spoke in Kibangi. It is not necessary to suppose that Hanssens spoke directly with the interpreter in some other language, since there might have been a chain of interpreters. At this date the language would have had to be Pidginized Kongo; Kiteke, the Bantu language in the region of Stanley Pool; Swahili; or a Bantu jargon, the proto-form of Bangala. This statement oversimplifies the case, but a fuller account can only be made in the context of discussing the history of the Congo River in the way that we are discussing that of the Ubangi. It would nonetheless appear from the expression 'his interpreter' that Hanssens's man came from downriver.

The first French expeditions on the Ubangi were not too different from Veistroffer's in January of 1889 . This he made from Modzaka, the northernmost French station on the Ubangi at that time, to which Veistroffer had been assigned at the beginning of the year. He travelled to the rapids at the bend of the river, where another post was to be established in June of that year (which came to be known as Bangui). He had with him only twelve men (some of whom were undoubtedly armed) and "mon cuisinier interprète" (1931:155). This is his "petit boy Alfa" ( I93 I: 195), a Loango from the coast. (Being the name of a port on the west coast, north of the mouth of the Congo River, there is not much chance of error in assuming that he spoke some form of Kikongo, including the pidginized variety, and even a bit of Portuguese.) The child could not possibly have known very much at all in the Ubangian language found at Modzaka for the trip. His primary function, I am sure, was to be intermediary between Veistroffer and his own men. (A characterization of the role of the interpreter will be given below.)

If the lower Ubangi populations (those between Bangui and the mouth of the river) had had contact with the Bantu-speaking peoples south of them, there might well have been a number of them conversant in one of their languages. One could cite, as evidence of this bilingualism, the fact that when P. Allaire went to a Bondjo village from the mission St. Louis at Liranga in May of 1890 , he used an interpreter to go through the rite of blood exchange with its chief 
(Galinand n.d.:55). The problem here is partly in identifying this "Bondjo" community because, as I have demonstrated elsewhere (Samarin I984a), the term was very imprecise and the ethnicity of the "Bondjo" was largely the work of white imagination. Soon after this, Galinand reports (6o), P. Allaire stops using an interpreter. We can assume that he felt that he had acquired enough of what he probably called "the language" to carry on his own transactions. (He was busy purchasing slave children for the mission.)

It is quite reasonable to suppose that $\mathrm{P}$. Allaire was learning to use the upper Congo contact language, the pidgin that was to become known as Bangala. However, there is evidence to suggest that he spoke Kiteke, at least at a later date (P. Prat, Alima, 22 October 1902, Congrégation du Saint-Esprit et du SaintCoeur de Marie, Fribourg [CSE-F].)

At this time, when whites were just beginning to come up the Lower Ubangi, the indigenous population would have been familiar with Kibangi, the language of the Bobangi further downriver, as we have already seen. The Bobangi specialized in trading, as whites had noted, starting with H. M. Stanley. But the amount of bilingualism should not be overestimated. When Froment was at Impfondo in I 888, aided by several Bobangi guides, he had difficulty in communicating with the chief (Froment I 889:206). Lack of competence, of course, may not have been the difficulty at all. It is possible that, not wanting to deal with Bobangi interlopers or not wanting to do what Froment was asking, the chief simply pretended he did not understand.

French reliance on "interpreters" was very great. The whites must have simply believed that their own blacks were able to "pick up" and débrouiller in the indigenous idioms. There is indeed one such statement. E. Ponel, administrator at Bangui, wrote that Amady-Paté, a Senegalese soldier who had been "garde-pavillon" stationed among the Ban-Ziri (that is, Gbanziri), presumably just upriver of Bangui and possibly at Bembe, had been assigned to the Crampel expedition as "courrier-interprète . . . à raison de son aptitude à apprendre les idiomes indigènes" (Bangui, 26 January I89I, AN 4(3)DI).

At the new post of Bangui, between the time when it was founded in June I 889 and when Musy, its second-in-command, was killed, the "homme de tête" was a Bassa "milicien" and interpreter. (The Bassa are people from the west coast of Africa in what is now Liberia.) But there was another interpreter, corporal William Cole, from whom information about the loss of Musy and his men was obtained, who "ne comprenait que quelques phrases du langage indigène" (Crampel I 891:142-43). Musy himself had written in private correspondence on 4 November 1889 that he had sent twenty-six of his men to the interior village of Botambi to buy food, when they would be gone for two or three days (Musy I891:214). In contacts of this sort, his men must have picked up their "quelques phrases" in the local language, which must have been Ngbaka.

In the very first years, the Senegalese personnel were the ones who served 
most frequently as interpreters. In fact, they were the staff on whom the French leaned, just as Stanley and then all the representatives of the Congo Free State did on the Zanzibaris in its early years. If on the plantations of the New World there were black stewards to boss the slaves, so the Muslim East and West Africans got the jobs done for the French and Belgians.

On 8 May I890, the commander at Bangui writes to Julien, "Le Sénégalais Collo-Maïssa je renvoie avec vous à Modzaka pour vous servir d'interprète. . ." (Ponel, AN 4(3)DI). Whatever competence this man had, it must have been in one of the local languages (from the dialect clusters of Gbanziri, Ngbaka, or Banda) or Bangala. Later that year, for example, Julien (whose location is unknown, but possibly Modzaka) was being instructed by his commander to hire Bondjo, that is local workers (Ponel, AN 4(3)DI, Bangui, 5 November I 890). In the next year, they were getting bamboo from nearby villages (Yakoli, Zongo, Bogâni, Songobio, Rénguekou, Kri-Ngoma), but also recruiting canoers from among the Gbanziri from as far away as a five- to six-day walk, enticed by payment in beads; Ponel's force at Bangui consisted of only nineteen soldiers, fourteen of whom were Senegalese and five Pahouins (Ponel, Bangui, 30 March I89I, AN 4(3)DI). (Although such information about contact with the indigenous populations and also the work force of the French is crucial for understanding the linguistic communication at this time, we cannot go into it further here.) What is more likely, as I try to demonstrate from linguistic evidence in Samarin (I982a), is that Julien's interpreter was undoubtedly more or less competent in the use of a jargon (possibly very idiosyncratic and personal in nature) relying on all that he had learned about central African languages. We, of course, have no way of knowing how much he could talk about in this way.

In this first year of French presence on the upper Ubangi, contact with the indigenous populations must have been infrequent and tenuous, in spite of the talk of "interpreters." The following must be considered a significant description of the situation:

A vrai dire, la politique suivie par les Europèens ici ne peut qu'amener des résultats plus fâcheux encore. Tous les agents, français aussi bien que belges, ne se préoccupent nullement d'entrer en relations avec les indigènes. On n'a même pas encore des deux côtés [that is, Belgian and French] formé un seul interprête! (Crampel in a confidential letter to the sous-secrétaire d'État aux Colonies, 30 October I 890; quoted by Kalck I970(2):388-89.)

It is possible, of course, to interpret the expression "train an interpreter" as referring to someone from the local population, which would require that he would learn some French - which is unlikely, given the black-white relations or one of the languages spoken by the expatriate black personnel. The way this training was accomplished is made clearer below.

Foreign blacks were expected to pick up local languages willy-nilly, so to 
speak, and their white superiors encouraged the process. Dybowski tells how he did this in I 89I, the year expeditions were going further upriver and also inland north and east of Bangui.

J'avais eu le soin de faire envoyer préalablement, chez le chef Bembé, deux de mes tirailleurs, afin qu'ils pussent apprendre la langue et nous servir d'interprètes. Il y avait un mois à peine qu'ils habitaient le village banziri, et déjà ils s'expliquaient aisément dans cette langue simple et facile" (Dybowski I 893:2 I6).

This would appear to be an important attestation, given the chronology of French occupation of this upper region of the Ubangi. The village must be the same as Bembe-Djoumara, where "gardes-pavillon" were established in January of I 89 I with three Senegalese soldiers, but its chief is identified as its "Chef de Poste et interprète" (all of this is from Ponel at Bangui, AN 4(3)Di, January I891).

No good idea of the competence of the interpreters can be gained without giving some consideration to the opportunities they had for acquiring languages; and in this there was a time factor. There is very little information about this topic, although we can make some fairly good guesses when we have precise dates for various expeditions. Unfortunately, this latter kind of information is scarce. In addition to the little that has already been given above, we can cite the case of J. E. Lawson, who was recruited in Dahomey and joined the de Béhagle mission at Porto Novo on I6 June I 897 and left it (at an unknown location) on 26 November 1899. During some of this time, he was both interpreter (with language unspecified: Ngambay, Sango, Banda, Chad Arabic, Fulani?) and warehouse guard (AN 2DI2). He must have learned a language at Fort Archambault, because in writing about this expedition, Chapiseau noted that when they went from the Ubangi River into the Chad they did not have any interpreter in a local language ("pas d'interprètes de la langue du pays") (I900:19I).

\section{ROLES AND RELATIONSHIPS}

The model that links interlocutors in a linear manner, like the visual one that is used for Julien's experience on the Kotto (or Kota) River (for which see Figure I), distorts or misrepresents the reality of linguistic interchange. What must be added to the description is a characterization of the roles played by the participants in verbal exchange and the nature of their relationships. If we do not do this, we portray history as falsely as does the cowboy fiction of the American nineteenth century.

The structure was a hierarchical one. This was due partly to the military or quasi-military organization of expeditions. (Military personnel were frequently lent to commercial expeditions, and even lines of command and responsibility appeared to get blurred.) It was also due to purely pragmatic matters: the need (or 


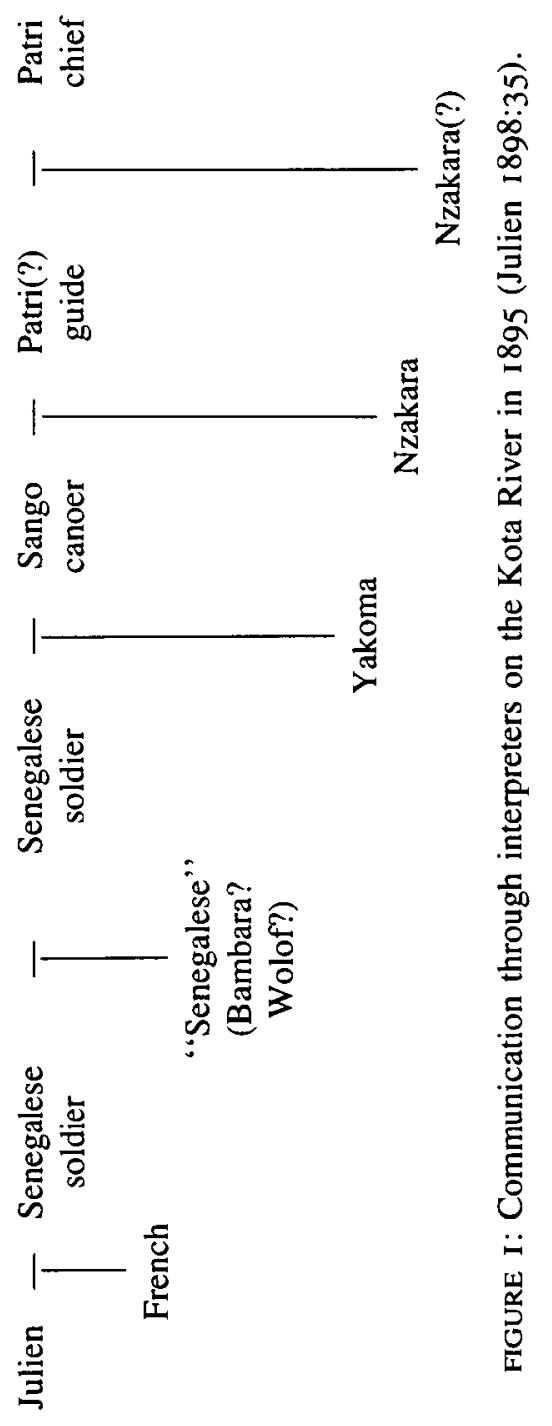


supposed need), for example, of a military escort (of one or more armed men), lent to travellers by the military commander.

In other words, the social structure underlying all contacts, whether explicit and intrinsic in white expeditionary units or de facto in the relationships established with indigenous populations, was one of power. It rested in the greatest degree with the whites (and with that particular white who was in command) and was distributed hierarchically through various levels of blacks. At each "level" there were rights and privileges, and these were realized through the use of force (or the threat of force) as well as the manipulation of language.

The linguistic consequence of this social structure (never rigid, of course; constantly changing as personnel and people's roles and skills changed) is that there was more or less linguistic interchange and of one kind or another depending on who was talking to whom. The white had the greatest amount of power, but it was distributed realistically or symbolically through the ranks. Next came the blacks who were in most contact with him: the military personnel under his immediate command and his servants. (Up until the end of the colonial administration in Ubangi-Shari, I can testify, the role of "boy" [house servant, factotum] was prestigious indeed.)

This topic, while of indubitable relevance to our present discussion, cannot be fully developed here. Its proper place is in the treatment of colonial expeditions as social, military, and work forces. A couple of cases must suffice to illustrate the point that is being made.

The first has to do with the interpreter Ali in an expedition north of Bangui in I 892. Brunache writes that Ali suggested giving gifts in connection with signing a treaty with Azamgounda and Gonno: " $\grave{A}$ son avis, une augmentation de cadeaux et même une distribution aux assistants donnerait beaucoup plus d'éclat à la cérémonie. Il oublie d'ajouter que cette façon de procéder augmenterait son importance et arrondirait sensiblement sa bourse en sa qualité d'interprète" (I894:I5I, see also I7I). There is plenty of evidence in the literature of the nineteenth century that whites tolerated the abuses of black subordinates (to a certain generous limit) as long as the former got what they wanted. But this is surely one of the best instances where a "child shall lead them" to his own advantage! This was the very same Ali - "le petit Ali" - who had been discovered shortly before this incident took place, as we saw above. When Brunache writes that Ali was "quite willing to serve as guide," he was underestimating this child's entrepreneurship (Brunache I894:I47)!

The following quotation illustrates this privileged behavior as well as it does the stratification of the personnel. It is from a slightly later period (I904-I905), and takes place at Krebedje, which became Fort Sibut.

Mon 'boy' loango, que je ne frappe jamais, n'hésite pas à frapper mes porteurs banda et mandjias; j'ai quelque peine à l'empêcher d'utiliser sur le 
dos de ses frères noirs la 'chicotte' dont je me sers seulement pour cravacher mon cheval; à mes observations il répond très calme: 'eux beaucoup sauvages.' Mon 'boy' s'est procuré, pour se faire servir, un petit domestique mandjia, qu'il rémunère des restes de nos repas. Notre caravane s'accroît ainsi peu à peu. Il y a les 'boys' des 'boys,' et les 'boys' Sénégalais (Challaye 1909:89).

On the use of force by a Senegalese to make porters work in $1898-1899$, see Colrat (I902:I55); on the way a Senegalese corporal established personal bloodbrother relationships with chiefs and had "a real influence in the whole area" about I895, see Mangin (1936:44).

\section{LIMITED LANGUAGE FOR LIMITED GOALS}

What the preceding analysis demonstrates is the fortuitous character of linguistic communication in the Ubangi River basin during the first years of colonization. Interpreters of whatever source and of whatever degree of competence were relied on heavily to achieve the ends of the colonial enterprise. Whites appear to have had very little direct linguistic contact with the indigenous peoples. The explanation for this fact lies, as this paper has suggested, both in pragmatic constraints and also in attitudinal factors. The first led them to delegate responsibility to their foreign black employees; the second restricted what they learned and how they used it. In a $0-$ Io scale of linguistic competence (where Io is that of the native speaker), whites must have been satisfied with something between 0 and I. It was always "words" and "useful phrases" they collected. (Note how Brunache [1894:206] described the way the Senegalese soldiers managed with their assortment of words.) And although they sometimes spoke of learning a language (or dialect or idiom), the concept of a rule-governed, that is, grammatical, entity seems to have been a weak one among most whites.

This interpretation of colonial sociolinguistic history is not inconsistent with the statement by Jeannest quoted above: 'It is extremely useful to know a little of the language ...' A little, we would say, obviously does not accomplish very much, but there were times when that little was 'extremely useful' for colonizing whites. Apart from the self-evident fact that it is better to know something than to know nothing at all even though one never knew when one's knowledge would prove helpful or critical (since just the word for water could prove useful on some occasion), language could always be used - and always with certain effectiveness - in its expressive function. The referential function for whites was therefore limited and gradient, depending, for example, on personal knowledge and immediate context. But speech, in and of itself, was the emblem and seal of the white man's message and person. 
The European, whenever he saw fit, interjected himself into the interminable palavers; he thus declared his authority over all interlocutors. He could do this by simply saying a few words. He was undoubtedly ignorant of the fact that African protocol required that serious discussion be mediated through spokesmen. The white's personal intervention was consequently brutal (ngangu in the pidginized language that was to emerge) and in fact brutalizing. The white man, however, saw it as effective: as 'extremely useful.' Confronted with such violent language (because direct, forceful, and uncompromising), the Ubangian, accustomed to mediation and face-saving strategies, would have capitulated.

This is an interpretation that is founded on African ethnography and my own personal experience. But there is one incident in the historical record that illustrates the thesis and constitutes a summary of this paper. On one occasion in I 895, P. Goblet was trying to get some children for the Sainte Famille mission school from a Sebanga chief. The discussion must certainly have been going on through an interpreter. When it proved futile, the missionary ended it with the declaration, probably accompanied by a gesture toward the chief and a look of disgust or disappointment, Kama pepe! (F. Goblet I932:153; cited also in R. Goblet, CSE-P, V. I8I.B:I79). ${ }^{2}$

This ejaculation illustrates the role-defining, expressive function of language, and it epitomizes the effectiveness of a minimal pidgin utterance. The missionary translated the phrase himself according to what he intended to convey: "Plus camarade"' ('[You are] no longer [my] friend'). But without a gesture, it could have meant 'There is no friend', and so on. The first word (glossed 'comrade') is possibly Gbanziri (that is, Ubangian), but the second is a negative imported from elsewhere (Samarin I982a), deviating drastically from the syntax of Ubangian languages. Not only is this utterance illustrative of a lexically mixed language, but it is also deficient in that it lacks a pronoun. The absence of a copula is, on the other hand, ambiguously deficient. If P. Goblet's model was vernacular Sango, he would not have used a copula because that language has none. (It is very unlikely that this was his conscious model, because of the three languages he attributed to the people with which the missionaries were in constant contact, Sango is not mentioned. However, his model was very likely the speech of his foreign workers, most of whom would have been in contact with speakers of Sango and related dialects.)

P. Goblet had the last word - only two, but with this limited declaration he delimited, for a period of time at least, the persons and statuses of the Negro and the European. The event was recorded by him as some kind of achievement.

\section{CONCLUSION}

Whereas the methodology of this study of the history of Pidgin Sango has been historical, the perspective has been that of the ethnography of communication. 
Indeed, I accept as axiomatic that pidgin origins cannot be fully explained without the paradigm that requires that we specify who spoke what to whom, in what manner, for what purpose, and under what circumstances. Such information is indispensable in the search for general principles that govern the rise and development of pidgins.

This paper has suggested that the vast majority of whites who came to central Africa had very little knowledge of what Bantu languages were like, and that they could not possibly have known anything about the Ubangian languages, which are structurally very different from the Bantu ones. Moreover, in the earliest years of the occupation of the Ubangi basin, they made very little serious attempt to acquire linguistic skills. Rather, they relied almost entirely on their foreign black personnel, who, because of their intimate contact with the indigenous peoples, arrived at an ad hoc means of communication, aided by the existence of multilinguals everywhere they went.

The "who" of the communicative paradigm must be specified with respect to roles and statuses, illustrated in the history of Sango by differences, on the one hand, between whites and foreign blacks, and, on the other, between these latter and natives.

What remains to be adumbrated is the nature of the changes that colonial contact initiated in communicative patterns. The use of children as servants and in other capacities by both whites and foreign blacks introduced these local children to new ways of talking with adults. Thereby, not only was a colonial speech network created, but also a colonial speech field. This development must have been exploited by the elders of these children and also among the foreigners. It is therefore reasonable to assume that these children and youth played a significant role in the creation of Pidgin Sango. This conclusion, arrived at deductively from the kind of data presented in this paper, is supported by explicit statements. Doctor Briand, who claimed to have made some attempt at learning what was already recognized as vehicular Sango during his eighteen months at Bangui in $1898-1899$, had as his principal teacher his own twelve-year-old servant, Samedi ('Saturday'). Since Bangui was established by the French only in 1889 (just two years after the first white explored the area), the boy may have grown up in the very context that had produced, in ten years or less, the idiom that was to be stabilized as Pidgin Sango. While he was a child who "led" his white "patron," he must have been preceded by other such children.

\section{NOTES}

1. But because of inconsistency in the use of quotation marks with ethnic names, there may have been no ambiguity at all.

2. The incident cited here was recorded in a letter dated 12 November 1895 , when P. Goblet was twenty-six years old. He had arrived at the mission only on I May of that year, just a month and a half after setting foot in Brazzaville. A different interpretation of his narrative would make the priest chide the chief for not having given him gifts (e.g., goats, chickens, etc.). 


\section{REFERENCES}

Alexandre, P. (1967). Langues et langage en Afrique noire. Paris: Payot.

Alis, H. [Jules-Hippolyte Percher]. (I89I). À la conquête du Tchad. Paris: Hachette.

Archives Nationales (AN), Section d'Outre-Mer. Aix-en-Provence. Archives du Gouvemement Général de l'Afrique Equatoriale Française. Sous-série 4(3)D: Oubangui-Chari, 1889-I942.

Baker, P., \& Corne, C. (I982). Isle de France Creole: Affinities and origins. Ann Arbor, Mich.: Karoma.

Bickerton, D. (1984). The language bioprogram hypothesis. Behavioral and Brain Sciences 7:17322 I.

Bouquiaux, L. (I982). Des chercheurs sans chaise longue: plaidoyer pour les sciences molles. Paris: Editeur Atelier Alpha Bleue.

Brunache, P. ( 1894 ). Le centre de l'Afrique: autour du Tchad. Paris: Ancienne Librairie Germer Baillière \& Cie.

Challaye, F. (1909). Le Congo français: la question internationale du Congo. Paris: Félix Alcan.

Chapiseau, F. ( I 900). Au pays de l'esclavage: moeurs et coutumes de l'Afrique centrale, d'après des notes recueillies par Ferdinand de Béhagle. Paris: J. Maisonneuve.

Cole, D. T. (I97 I). The history of African linguistics to I945. In T. Sebeok et al. (eds.), Linguistics in Sub-Saharan Africa. (Current Trends in Linguistics 7.) The Hague and Paris: Mouton. I-29.

Colrat de Montrozier, R. (1902). Deux ans chez les anthropophages et les sultans du centre africain. Paris: Librairie Plon.

Congrégation du Saint-Esprit et du Saint-Coeur de Marie, Paris and Chevilly-Larue, France (the Holy Spirit Mission) (CSE-P). Archives.

Congrégation du Saint-Esprit et du Saint-Coeur de Marie, Fribourg, Switzerland (CSE-F). Personal correspondence of Mgr. Prosper Augouard.

Coquilhat, C. ( 1888 ). Sur le Haut-Congo. Paris: J. Lebègue \& Cie.

Crampel, P. (I89I). Lettre de M. Crampel à M. Musy père. Revue de Géographie 29:141-43.

Cust, R. N. (1883). A sketch of the modern languages of Africa. London: Trubner and Co.

Delcommune, A. (1922). Vingt années de vie africaine, 1874-1893: récits de voyages, d'aventures et d'exploration. 2 vols. Bruxelles: Veuve Ferdinand Larcier.

de Mazières, A.-C. (1982). La marche au Nil de Victor Liotard: histoire de l'implantation française dans le Haut-Oubangui 1891-1899. Aix-en-Provence: Université de Provence.

Dias-Briand, M.-C. (1982). Les archives de Joseph Briand, médecin à Bangui I898-I900. Aix-enProvence: Institut d'Histoire des Pays d'Outre-Mer, unpublished Mémoire de maîtrise.

Dybowski, J. ( 1893 ). La route de Tchad du Loango au Chari. Paris: Firmin-Didot.

Froment, E. ( 1889 ). Un voyage dans l'Oubangui de Lirranga à Modzaka. Bulletin de la Sociêté de Géographie de Lille I I I 80-216.

Galinand, (P.) J. (n.d.). Le R. P. Allaire, missionnaire au Congo d'après ses écrits et sa correspondance. Paris and Poitiers: Librairie H. Oudin.

Goblet, (Abbé) F. (I932). Journal et correspondance du R. P. Raoul Goblet: Oubangui-Chari 1894I897. Journal de voyage et correspondance addressé à son frère, l'abbé Frédéric Goblet. Paris: Imprimerie des Orphelins-Apprentis.

Goblet, (R. P.) R. Journal du R. P. Raoul Goblet, missionnaire apostolique de l'Oubanghy à la Mission de la Sainte Famille des Banziris, contenant la relation de son voyage de Marseille à Brazzaville, 25 Oct. 1894. CSE-P, Chemise V, Boîte 181, Dossier B. Three notebooks.

Greenberg, J. H. (1963). The languages of Africa. The Hague: Mouton.

Hanssens, (Cpt.) E. (I 892). Les premières explorations du Haut Congo: lettres inédites du capitaine Hanssens. Le Congo Illustré 1:5-7, 13-15, 22-23, 29-3 I, 37-39, 45-47.

Harms, R. W. (1978). Competition and capitalism: The Bobangi role in equatorial Africa's trade revolution, ca. $1750-1900$. $\mathrm{Ph} . \mathrm{D}$. thesis, University of Wisconsin, Madison.

(198I). River of wealth, river of sorrow: The central Zaire basin in the era of the slave and ivory trade, 1500-189I. New Haven: Yale University Press.

Hoenigswald, H. M. (1966). A proposal for the study of folk-linguistics (with Discussion by D. Hymes, E. Haugen, C. Ferguson, P. Friedrich, W. Samarin, W. Labov, P. Garvin, W. Bright, H. Paper). In W. Bright (ed.), Sociolinguistics: Proceedings of the UCLA sociolinguistics conference. 1964. The Hague and Paris: Mouton. 16-26. 
Jeannest, C. (1883). Quatre années au Congo. Paris: G. Charpentier \& Cie.

Julien, (Cpt.) É. (1898). Du Haut-Oubangui vers le Chari par le bassin de la rivière Kota (Ier mai-5 octobre 1895), accompagné d'une carte. Paris: Société de Géographie.

(1902). Exploration du capitaine Julien de la haute Banghi à la Yéouka et le long de l'Oubanghi. La Géographie (Bulletin de la Société de Géographie) 5:216-18.

Kalck, P. (1970). Histoire centrafricaine des origines à nos jours. Thèse présentée devant la Faculté des Lettres et Sciences Humaines de Paris. 4 vols.

(1974). Histoire de la République Centrafricaine des origines préhistoriques à nos jours. Paris: Berger-Levrault.

Legendre, P. (1903). La conquête de la France africaine. Paris: La Librairie Mondiale.

Lepsius, R. (1855). Standard alphabet for reducing unwritten languages and foreign graphic systems to a uniform orthography in European letters (recommended for adoption by the Church Missionary Society). London: Seelys.

Maistre, C. (1893). [Report of journey in 1892-1893]. Société de Géographie [de Paris]: Comptes rendus des séances, nos. I2-13, séances de 9 et 16 juin I893:270-87.

(1895). À travers l'Afrique centrale du Congo au Niger, 1892-1893. Paris: Hachette \& Cie.

Mangin, (Gen.) C. (1936). Souvenirs d'Afrique: lettres et carnets de routes. Paris: Denoël et Steele.

Meinhof, C., \& van Warmelo, N. J. (1932). Introduction to the phonology of the Bantu languages. Berlin: Dietrich Reimer/Ernst Vohsen.

Mühlhäusler, P. (1983). Samoan plantation Pidgin English and the origin of New Guinea Pidgin. In E. Woolford \& W. Washabaugh (eds.), The social context of creolization. Ann Arbor, Mich.: Karoma. 28-76.

Musy, M. (1890-1891). Correspondance de M. Maurice Musy, chef de poste à Bangui (Congo français), massacré par les indigènes. Revue de Géographie 27 (1890):375-81, 455-57; 28 (1891):64-68, 130-33, 21 I-14, 291-94; 29 (1891):62-66.

Prioul, C. (1981). Entre Oubangui et Chari vers 1890. Paris: Société d'Ethnographie et de Sociologie Comparative, Université de Paris X.

Samarin, W. J. (1971). Adamawa-Eastern. In T. Sebeok et al. (eds.), Linguistics in Sub-Saharan Africa. (Current Trends in Linguistics, 7.) The Hague and Paris: Mouton. 213-44.

( $1982 a)$. Colonization and pidginization on the Ubangi River. Journal of African Languages and Linguistics $4: 1-42$.

(1982b). Goals, roles, and language skills in colonizing central equatorial Africa. Anthropological Linguistics 24:410-22.

(1984a). Bondjo ethnicity and colonial imagination. Canadian Journal of African Studies in press.

(1984b). Socioprogrammed linguistics. Behavioral and Brain Sciences 7:206-07.

(1984c). La communication par les eaux et les mots oubanguiens. In Recherches centrafricaines: Problèmes et perspectives de la recherche historique (Études et documents, I 8). Aix-enProvence. Institut d'Histoire des Pays d'Outre-Mer (Université de Provence). 179-239.

(n.d.). Plurigenesis in pidginization. Manuscript.

Thomas, J. M. C. (1963). Le parler Ngbaka de Bokanga: phonologie. morphologie, syntaxe. The Hague and Paris: Mouton.

Van Gèle, A. (1930). Le Capitaine Hanssens. In Le vieux Congo: souvenirs recueillis par Léo Lejeune. Bruxelles: L'Expansion belge. 32-42.

Veistroffer, A. (193I). Vingt ans dans la brousse africaine: souvenirs d'un ancien membre de la mission Savorgnan de Brazza dans l'Ouest-africain (1883-1903). Lille: Mercure de Flandre/Valentin Bresle.

Wonderly, W. L., \& Nida, E. A. (1963). Linguistics and Christian missions. Anthropological Linguistics 5(1):104-44. 